\title{
EX OFFICIO KEPALA KANTOR URUSAN AGAMA KOTA LANGSA DALAM PENYELESAIAN PERMASALAHAN WALI ADHAL
}

\author{
M. Affas Edward \\ Penghulu KUA Langsa Baro, Aceh \\ Email: m.affasedward@gmail.com
}

\begin{abstract}
The people in Langsa City understand that when a wali adhal is considered more competent to solve it is the Office of Religious Affairs (KUA), because it is considered to have a better understanding of marriage issues. Whereas in regulations the juridical authority to resolve the problems of wali adhal is the religious court. The purpose of this research is based on the normative and sociological authority of the settlement of wali adhal. This research is field research with a sociological approach. The results show that there are several factors in the occurrence of wali adhal and the Office of Religious Affairs (KUA) is actively resolving wali adhal problems with mediation, emotional approach, discussion approaches and when the approach fails to be resolved by means of litigation.
\end{abstract}

Keywords: Ex officio, wali adhal, Office of Religious Affairs (KUA)

\begin{abstract}
Abstrak
Masyarakat Kota Langsa memahami bahwa ketika terjadinya wali adhal yang dianggap lebih kompeten menyelesaikannya adalah Kantor Urusan Agama karena dianggap lebih memahami masalah pernikahan. Padahal dalam Undang-Undang mengatur tentang kewenangan secara yuridis yang menyelesaikan permasalahan wali adhal adalah Mahkamah Syar'iyah. Tujuan penelitian ini untuk menganalisis kewenangan secara normatif dan sosiologis penyelesaian wali adhal. Jenis penelitian field research dengan pendekatan sosiologis yang digunakan dalam penelitian ini. Hasil penelitian menunjukan bahwa ada beberapa faktor terjadinya wali adhal dan Kantor Urusan Agama secara aktif menyelesaikan permasalahan wali adhal dengan pendekatan mediasi, emosional, musyawarah dan ketika pendekatan tersebut gagal diselesaikan dengan cara litigasi.
\end{abstract}

Kata Kunci: Ex officio, wali adhal, Kantor Urusan Agama 


\section{Pendahuluan}

Wali nikah merupakan bagian penting dalam proses pernikahan yang tidak dapat dianggap mudah, dalam Pasal 19 pada Kompilasi Hukum Islam menjelaskan bahwa wali nikah merupakan bagian terpenting dalam pernikahan, kerena wali nikah adalah bagian dari rukun nikah yang memiliki fungsi sebagai orang yang akan menikahkannya. Ketika dilihat dalam konteks tersebut, maka calon mempelai harus menghadirkan wali dan ketika tidak ada wali maka pernikahannya tidak sah secara hukum Islam dan hukum negara, apalagi dalam undang-undang pernikahan menegaskan juga bahwa pernikahan sah apabila dilakukan menurut agama dan kepercayaan masing-masing. Selain itu, dalam kitab fiqh juga secara ketat mewajibkan keberadaan wali dalam pelaksanaan akad perkawinan dan menjadi bagian penentu sah atau tidaknya perkawinan. ${ }^{1}$ Sebagaimana sabda Nabi yang menegaskan bahwa pernikahan tanpa izin wali batal. ${ }^{2}$

Dalam masyarakat Kota Langsa, permasalah wali nikah yang terjadi berkaitan dengan pemahaman tentang wali fasiq, wali hakim dan wali adhal. Diantara permasalahan wali nikah tersebut yang paling sering terjadi adalah permasalahan wali adhal. Meskipun pada kenyataannya masyarakat banyak tidak mengerti dengan kehadiran wali adhal, akan tetapi wali adhal dengan sendirinya hadir ketika wali nasab atau wali mujbir tidak ingin menjadi wali nikah. Dalam konteks wali adhal Imam Malik dan Syafi'i menyatakan bahwa ketika wali menghalangi anak perempuannya menikah dengan pasangan sekufu baginya dan dalam kondisi tersebut anaknya rela dan setuju untuk menikah, maka secara hukum wali tidak secara otomatis berpindah kepada wali ab'ad, akan tetapi jalan yang dapat ditempuh oleh anaknya yaitu dengan melapor pada hakim, setelah itu hakim meminta klarifikasi kepada wali dan apabila tidak ditemukan titik temu penyelesaian maka hakim dapat betindak untuk menikahkannya. ${ }^{3}$ Wahbah Zuhaili menegaskan kembali bahwa penolakan wali untuk menikahkan anaknya (perempuan) yang secara hukum sudah baligh dan berakal dengan pria yang sekufu dan mereka saling mencintai satu sama lainya apalagi anaknya telah meminta kepada walinya untuk menikahkannya dan wali menolak maka penolakan wali terhadap permintaan maulanya termasuk melanggar syariat tentang perwalian dalam pernikahan dan hal ini dilarang dalam Islam. ${ }^{4}$

Selain dalam fikih munakahat, permasalahan wali adhal juga diatur dalam Kompilasi Hukum Islam yang dijelaskan dalam Pasal 23. Dalam Kompilasi Hukum Islam hanya mempertegas apa yang telah dibahas dalam kitab fikih yaitu berkaitan dengan terminologi wali adhal dan perpindahan wali ketika adhal. Perpindahan

\footnotetext{
${ }^{1}$ Moch. Azis Qoharuddin, "Kedudukan Wali Adhal Dalam Perkawinan," El-Faqih : Jurnal Pemikiran dan Hukum Islam 4, no. 2 (Oktober 30, 2018): 99-122, https://doi.org/10.29062/faqih.v4i2.44.

${ }^{2}$ Abu Daud Sulaiman al-Asy`ats al-Sijistani, Sunan Abi Daud, Vol. 2 (Beirut: Maktabah al-`Ashriyyah, tt).229

${ }^{3}$ Abdurraḥman al-Jaziri, Kitab Al-Fiqh Alal Mazahib al-Arba'ah, vol. 3 (Beirut: Dār al-Fikr, tt).

${ }^{4}$ Wahbah Zuhaily, Fiqh Islamî Wa Adillatuh, Vol. 9 (Beirut: Dār al-Fikr, 1997).6720
}

M. Affas Edward| Ex Officio Kepala Kantor Urusan Agama ..... 74 
wali adhal dalam Kompilasi Hukum Islam secara prosedur beralih kepada hakim ketika pihak terkait melaporkan perkaranya ke Pengadilan Agama atau Mahkamah Syari'ah di aceh. Jika mencermati secara legal formal proses penentuan wali adhal dalam kitab fiqh dan dalam KHI melalui putusan pengadilan, dalam KHI juga dinyatakan bahwa putusan hakim menjadi penentu pengganti wali dalam pernikahan. Secara hukum putusan hakim memiliki kekuatan hukum yang lebih besar, sehingga penentuan wali adhal tidak dapat digantikan sesuka hatinya karena ini menyangkut dengan sah atau tidak sahnya suatu pernikahan.

Pada dasarnya kasus di Kota Langsa tentang wali adhal yang sering terjadi, pada tahun 2018-2019 setidaknya ada 25 kasus, kebanyakan wali tidak setuju dengan calon pilihan anaknya disebabkan oleh berbagai hal, sebagaimana hasil observasi yang dilakukan di KUA Langsa Baro yang menyatakan bahwa wali adhal terjadi karena perbedaan latar belakang ekonomi, Pendidikan, keturunan dan sudah adanya calon yang dipilih oleh orangtuanya, dari pihak anak menginginkan suami dari pilihannya sendiri, sehingga terjadinya pertengkaran antara anak dan orang tuang dan mengakibatkan orang tua menolak menjadi wali nikah bagi anaknya. ${ }^{5}$ penyataan ini senada dengan beberapa penelitian yang dilakukan oleh Akhmad Shodikin, ${ }^{6}$ Hilma Syita El Asith ${ }^{7}$ dan Muhamad Affan Mubarok. ${ }^{8}$

Penelitian tersebut hanya melihat sudut pandang hukum tentang kebijakan hakim, mekanisme peralihan wali adhal, tidak melihat model penyelesaian secara non-litigasi tanpa mengesampingkan aspek hukum positif dan adat yang berlaku. Jika melihat dari sudut pandang hukum, maka proses pernikahan dapat dilakukan meskipun wali adhal dengan melalui proses pengadilan, padahal ada cara lain yang dapat diupayakan agar tidak melalui proses pengadilan dan yang semulanya wali adhal dapat berubah menjadi wakalah wali dengan menghadirkan pihak KUA sebagai penengah agar tidak terjadinya wali adhal. Disini dibutuhkan peran KUA dalam menyelesaikan permasalahan tersebut dengan berusaha mengupayakan agar masalah perwalian adhal tidak sampai ke pengadilan cukup diselesaikan dengan cara-cara lain. Kerena apabila melalui pengadilan, secara psikologis akan memperburuk hubungan antara anak dan orang tua bahkan dapat berujung kepada tidak diakuinya sebagai anak, hal ini sering terjadi di Kota Langsa bahkan terjadi secara berkelanjutan. Berdasarkan permasalahan inilah menarik untuk diteliti terkait dengan peran Kepala Kantor Urusan Agama (KUA) dalam penyelesaian permasalahan wali adhal di kota langsa.

\footnotetext{
${ }^{5}$ Irham, Wawancara Kepala KUA Langsa Baro, March 5, 2019.

6 Akhmad Shodikin, "Penyelesaian Wali Adhal Dalam Pernikahan Menurut Hukum Islam Dan Perundang-Undangan Di Indonesia," Mahkamah: Jurnal Kajian Hukum Islam 1, no. 1 (2016): 10.

7 Hilma Syita El Asith, "Dasar Pertimbangan Hakim Dalam Permohonan Wali," Al-Hakim: JurnallImiahMahasiswa : Studi Syariah, Hukum dan Filantropi 2, no. 2 (2020): 13.

${ }^{8}$ Muhamad Affan Mubarok, Eva Fauziah, and Ilham Mujahid, "Tinjauan Kompilasi Hukum Islam (KHI) terhadap Putusan Hakim Tentang Perkawinan Wali Adhal," Prosiding Hukum Keluarga Islam 6, no. 2 (2020): 38-31, http://dx.doi.org/10.29313/Islamic\%20family.v6i2.22207.
} 
Penelitian ini adalah penelitian lapangan (field research) dengan pendekatan sosiologis, Pendekatan sosiologis digunakan untuk menggambarkan tentang keadaan masyarakat serta berbagai gejala sosial tentang permasalahan wali adhal. Wawancara terstruktur merupakan metode pengumpulan data. Sumber data primer dalam penelitian ini adalah Kepala KUA selaku pegawai pencatat nikah (PPN) Kota Langsa. Aceh.

\section{Diskursus Wali Adhal Dalam Kajian Hukum Islam}

Wali adhal merupakan dua suku kata yang terdiri dari kata wali dan adhal. Secara bahasa wali memiliki makna pengampu, pelindung, penolong. ${ }^{9}$ Secara istilah wali merupakan orang yang memiliki kewenangan secara hukum dalam menikahkan anaknya atau dapat diartikan juga sebagai orang yang bertindak atas dasar hukum mewakili anaknya untuk melangsungkan akad pernikahan. ${ }^{10}$ Pengertian tersebut memberikan stigma bahwa yang dapat melegalkan pernikahan dalam hukum Islam adalah wali, meskipun ada syarat hukum lainnya. Bahkan dalam literatur fikih menegaskan tidak sah pernikahan tanpa adanya wali, ${ }^{11}$ hal ini sejalan dengan hadis Nabi yang menyatakan bahwa " lâ nikâha ila bi wali". ${ }^{12}$ meskipun ada yang berpendapat tidak wajib wali bagi wanita yang dewasa dan sehat akalnya. ${ }^{13}$

Sedangkan adhal secara etimologi berasal dari kata عضل - يعضل yang bermakna منعهـ (melarang/mencegahnya), ضـيّق (sempit), منـع المـرأة مـن الـزواج (menghalangi perempuan untuk menikah). ${ }^{14}$ Menurut istilah Wali adhal ialah wali yang menolak untuk menikahkan anak perempuannya yang sudah baligh dengan seorang lakilaki yang sekufu. ${ }^{15}$ Dalam al-quran kata adhal memiliki makna menghalangi sebagaimana dijelaskan dalam QS. Al-Baqarah 2:232.

Wahbah Zuhailiy (1932-2017 M) salah satu ulama kontemporer memberikan definisi tentang wali adhal yaitu; ${ }^{16}$

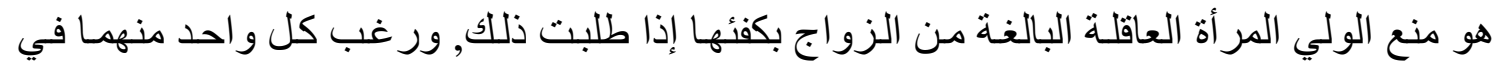

\footnotetext{
9 Rokhmadi Rokhmadi, "Penetapan 'Adam Wali Nikah Oleh Pejabat Kua Di Kota Semarang," AlAhkam 26, no. 2 (December 2, 2016): 203, https://doi.org/10.21580/ahkam.2016.26.2.992.

${ }^{10}$ Aayesha Rafiq, "Role of Guardian in Muslim Woman's Marriage: A Study In The Light Of Religious Texts," IJISET - International Journal of Innovative Science, Engineering \& Technology 2, no. 4 (n.d.): 8.

11 Abdu al-Rahman al-Jaziri, Al-Fiqh 'Ala Al-Mazâhib Al-Arba'Ah, vol. 4 (Beirut: Dār Al-Kutub Al'Ilmiyah, 1990).29

12 Siti Maryam Qurotul Aini, "Kedudukan Wali Dalam Pernikahan (Kajian Perbandingan Madzhab)," USRATUNA 1, no. 1 (2017): 20.

${ }^{13}$ Amir Syarifuddin, Hukum perkawinan Islam di Indonesia: Antara Fiqh Munakahat dan UndangUndang Perkawinan (Jakarta: Kencana, 2006).69

${ }^{14}$ Mustafa Al-Bugha Mustafa Al-Jin, Fiqh Âl-Manhaji 'ala Mazhab Al-Imâm Al-Syâfi'i, 13th ed., Vol. 2 (Damsyik: Dâr al-Fâth, 2012).64

${ }^{15}$ Al-Imam Nawawi, Raudhatu At-Thâlibin, Vol. 5 (Saudi Arabiya: Dâr 'Alam Al-Kutub, 2003). 304305

16 Zuhaily, Fiqh Islamî Wa Adillatuh. 6720
}

M. Affas Edward| Ex Officio Kepala Kantor Urusan Agama ..... 76 
Wahbah Zuhaili memahami bahwa wali adhal merupakan penolakan wali untuk menikahkan anak perempuannya yang berakal dan sudah bâliqh dengan laki-laki yang sepadan dengan perempuan itu. Jika perempuan tersebut telah meminta (kepada walinya) untuk dinikahkan dan masing-masing calon mempelai itu saling mencintai. Pengertian ini sama dengan yang dijelaskan dalam KHI Pasal 23 Ayat (2).yang menyatakan bahwa wali adhal adalah wali yang enggan menikahkan anaknya.

Berdasarkan definisi tersebut dapat dipahami bahwa yang dimaksud dengan wali adhal yaitu; pertama, Adanya Penolakan wali untuk menikahkan calon mempelai perempuan; kedua, Adanya permintaan atau permohonan dari calon mempelai perempuan agar dirinya dinikahkan dengan calon mempelai laki-laki; ketiga, Kafa'ah antara calon mempelai laki-laki dan calon mempelai perempuan; keempat, Adanya perasaan saling menyayangi atau mencintai di antara masing-masing calon mempelai; kelima, Alasan penolakan (keengganan) wali tersebut bertentangan dengan syariat.

Manyoritas ulama tidak melarang wali adhal, para ulama mencoba menguraikan beberapa aspek-aspek hukum yang terjadi ketika wali adhal. Mazhab Syafi'iyah, Hanabilah, Abi Yusuf dan Muhammad tidak memperbolehkan wali adhal jika alasan yang digunakan yaitu permasalahan mahar, karena mahar merupakan hak maula bukan walinya. sedangkan Imam Malik menyatakan bahwa boleh wali tersebut adhal apabila calon yang dipilih oleh maulanya tidak sekufu, begitu juga dengan mazhab Syafi'iyah dan Hanbali. ${ }^{17}$

Adhalnya wali berpengaruh terhadap penentuan wali nikah, apakah wali tersebut jatuh kepada wali ab'ad atau wali hakim. Hanafiah, Maliki, dan Syafi'i berpendapat bahwa ketika seorang wali menghalangi maulanya untuk menikah dengan pasangannya yang sekufu dan maula rela terhadapnya. Maka, perwalian tidak pindah pada wali yang jauh (wali $a b^{\prime} a d$ ) akan tetapi berhak bagi maulanya untuk melaporkan perkaranya kepada hakim, dengan maksud untuk mempertanyakan kepada wali mengenai sebab walinya adhal, apabila wali nashab tetap pada pendiriannya menolak menjadi wali nikah. Maka, wali nikah beralih kepada wali hakim. ${ }^{18}$ Pendapat ini berbeda dengan Ibn Rusyd yang menyatakan bahwa tidak berpindah ke wali hakim melainkan jatuh kepada wali selain wali aqrab;

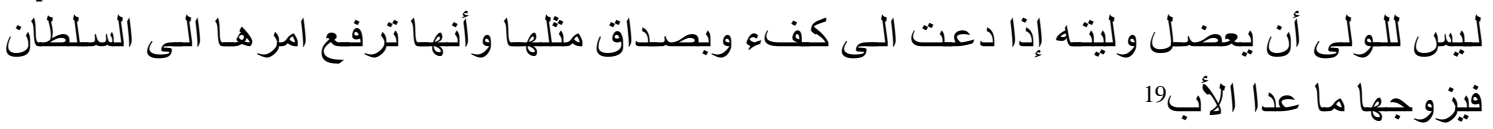

Maksud dari redaksi tersebut bahwa tidak berhak bagi wali menghalangi anak yang menginginkan pasangan sekufu dan dengan mahar mitsinya, maka

\footnotetext{
17 Zuhaily. 6720

18 al-Jaziri, Kitab Al-Fiqh Alal Mazahib al-Arba'ah.35

19 Ibnu Rusyd, Bidayatul Mujtahid Wa Nihayatul Muqtashid, trans. Al-Mas'udah, vol. 2 (Jakarta: Pustaka Al-Kautsar, 2016).22-29
} 
apabila wali mencegah hendaklah bagi perempuan melaporkan perihal tersebut kepada hakim. Imam Syafi'i dalam kitabnya al-Umm juga menjelaskan bahwa apabila para wali terjadi sengketa, hendaklah seorang hakim memperhatikan bahwa apabila wali tersebut adalah seorang wali yang adhal maka hakim memerintahkan kepada wali tersebut untuk menjadi wali nikah bagi anaknya (mengawinkan) dan apabila wali mengawinkan habislah masalahnya, tetapi apabila wali enggan mengawinkan maka teranglah pencegahan atau pembangkangannya dan kewajibannya sebagai wali hakim untuk mengawinkan atau mewakilkannya kepada orang lain uantuk mengawinkannya. ${ }^{20}$

Dalam KHI juga dijelaskan bahwa yang menjadi pengganti bagi wali adhal adalah wali hakim, ${ }^{21}$ begitu juga yang dijelaskan dalam PMA Nomor 30 Tahun 2005 Tentang Wali Hakim, Pada Pasal 5 Ayat (1) yang menyatakan bahwa Sebelum akad nikah dilangsungkan wali hakim meminta kembali kepada wali nasabnya untuk menikahkan calon mempelai wanita, sekalipun sudah ada penetapan Pengadilan Agama tentang adhalnya wali. Pada Ayat (2) ditegaskan lagi bahwa apabila wali nasabnya tetap adhal, maka akad nikah dilangsungkan dengan wali hakim.

\section{Permasalahan Wali Adhal di Kota Langsa, Aceh}

Wali adhal dalam Islam diatur untuk mempermudah ketika terjadinya permasalahan tentang wali, yang mana pada kondisi tertentu wali menolak untuk menikahkan anaknya, tujuannya yaitu agar pernikahan tetap berlangsung sesuai dengan ketentuan hukum Islam. Di Kota Langsa permasalahan wali adhal terjadi disebabkan oleh beberapa hal. Berdasarkan hasil penelitian yang dilakukan di KUA Kota Langsa didapati bahwa ada beberapa faktor terjadinya wali adhal antara lain; Pertama, Faktor Perbedaan Usia. ${ }^{22}$ Secara hukum perbedaan usia dalam pernikahan tidak dipermasalahkan. Permasalahan terjadi ketika batas minimal usia nikah. Perbedaan usia tidak menjadi malah dalam Islam. Pada praktiknya, perbedaan usia nikah antara masing-masing pasangan menjadi problem pada mayoritas masyarakat Langsa, Aceh. Hal ini menjadi permasalahan tersendiri ketika dihadapkan dengan realitas sosial. Rasa gengsi dan malu dengan tekanan issu masyarakat sehingga semakin mempengaruhi para wali untuk menikahkan anak perempuannya.

Kedua, Usia nikah. Ada perbedaan sudut pandanga tentang usia nikah antara normatif dan sosiologi. Secara normatif dalam dalam kajian hukum Islam menjelaskan bahwa usia pernikahan dilihat dari dua aspek yaitu aspek kualitas

\footnotetext{
${ }^{20}$ Abi Abdillah Muhammad bin Idris As- Syafi'I, Al-Umm, Vol. 3 (Beirut: Dār Al-Fiqr, 1983).14

${ }^{21}$ Muhamad Hasan Sebyar and A. Fakhruddin, "Pengambilalihan Wewenang Wali Nasab Dalam Perkara Wali Adhal Perspektif Pluralisme Hukum (Studi Kasus Pandangan Hakim dan Tokoh Masyarakat Kabupaten Pasuruan)," ADHKI: Journal of Islamic Family Law 1, no. 2 (February 4, 2020): 73-91, https://doi.org/10.37876/adhki.v1i2.19.

22 Itqan Fahmi, Wawancara Kepala KUA Langsa Kota, June 18, 2019.
}

M. Affas Edward| Ex Officio Kepala Kantor Urusan Agama .....| 78 
intelektual (rusydan)dan kondisi fisik (bâligh). ${ }^{23}$ Namun, praktik pernikahan pada masyarakat Langsa tidak hanya melihat dari aspek normatif saja, melaikan melihat dari aspek mental dan skill. aspek mental ditandai dengan keyakinan dan kesiapan untuk membina rumah tangga serta mengetahui kewajiban istri kepada suami, sedangkan aspek skill ditandai dengan kemampuan dalam menjalankan tugas Istri.

Bagi mayoritas masyarakat Aceh, wanita dianggap siap untuk menikah baik secara mental dan skill ketika sudah mandiri, bisa memasak, mencuci dan mengerjakan pekerjaan rumah, dengan begitu dianggap sudah mampu mengurus suami dan anaknya. Jadi bagi wanita yang dilihat tidak hanya usia saja tetapi kemandirian dalam mengurus rumah tangga menjadi pertimbangan penting. Sedangkan laki-laki dianggap sudah siap menikah apabila sudah berpenghasilan baik penghasilan tetap maupun tidak tetap, yang terpenting mereka mampu memberi nafkah kepada anak dan istrinya. ${ }^{24}$ Budaya seperti ini memang sudah menjadi kebiasaan mayoritas masyarakat aceh yang menekankan bahwa seorang istri seyogyanya mampu melakukan pekerjaan rumah dan bagi pria mampu memberikan nafkah.

Ketiga, Faktor ekonomi, permasalahan ekonomi salah satu pertimbangan penting oleh para wali nikah di Langsa, Aceh. Adhalnya wali karena alasan ekonomi merupakan masalah yang sering terjadi di KUA Langsa Lama, ${ }^{25}$ KUA Langsa Kota $^{26}$ dan KUA Langsa Barat ${ }^{27}$. Ketika calon suami pilihan anaknya tidak memiliki kejelasan finansial. Maka, para orang tua (wali) tidak mengizinkan untuk menikahi anak perempuannya. Kondisi ini wajar saja terjadi karena secara sosiologis ekonomi menjadi salah satu hal yang sangat dalam membina rumah tangga. Bahkan Rasul sendiri mensyaratkan mahar untuk menikah, sebagaimana ketika Rasul menikahkan sahabat dengan mahar cinci dari besi. ${ }^{28}$ Hal ini menunjukan bahwa dalam pernikahan dibutuhkan modal meskipun dengan jumlah yang sedikit.

Tidak dapat dipungkiri bahwa kebutuhan ekonomi menjadi tolak ukur keseriusan seseorang dalam menikah, karena untuk memenuhi kebutuhan pokok secara realitas perlu kejelasan meskipun tidak ada kepastian jumlah maksimal dan minimal. Abraham Maslow menyatakan bahwa;

"The needs that are usually teken as the starting point for motivation theoryare the so called physiological driven. Two recent lines of research make it necessary to revise our customary nations about these needs; first,

\footnotetext{
23 Moch Nurcholis, “Usia Nikah Perspektif Maqashid Perkawinan," Tafáqquh: Jurnal Penelitian Dan Kajian Keislaman 8, no. 1 (March 16, 2020): 1-18.

24 Muhazir, Wawancara Akademisi, October 15, 2020.

25 Khalilurrahman, Wawancara Kepala KUA Langsa Lama, June 17, 2019.

${ }^{26}$ Fahmi, Wawancara Kepala KUA Langsa Kota.

${ }^{27}$ Azhar, Wawancara Kepala KUA Langsa Barat, June 17, 2019.

28 Dian Ramadhan and Farah Ihza Fauzia Balqis, "Pandangan Mazhab Hanafi Dan Maliki Terhadap Jumlah Kadar Mahar Pada Akad Nikah," JAWI 3, no. 1 (2020): 18, http://dx.doi.org/10.24042/jw.v3i1.7036.
} 
the development of the concept of homeostasis, and seconf, the finding that appetites are a fairly efficient indication of actual needs or lack in the body". ${ }^{29}$

Kebutuhan utama yang dicari dalam keluarga selain kasih sayang tidak luput juga dari aspek ekonomi, karena ekonomi merupakan penunjang untuk mencari pemenuhan kebutuhan pokok seperti, makan, minum dan pemenuhan tempat tinggal. Sehingga secara psikologis wajar saja para wali mementingkan aspek ekonomi dalam pemilihan suami untuk anaknya.

Keempat, Status calon suami, ${ }^{30}$ hal ini juga menjadi salah satu penyebab wali adhal ketika anaknya ingin menikah dengan seorang pria yang berstatus duda, sedangkan anak perempuannya masih gadis sehingga orang tua merasa tidak terima kalau anaknya menikah dengan pria yang sudah pernah menikah. Penolakan orang tua (wali) terhadap status duda sebenarnya berkaitan dengan sikap gengsi dan menghindari pembicaraan negatif dari tetangga. Lagi-lagi pengaruh lingkungan secara langsung mempengaruhi spikologis para wali nikah sehingga solusi terakhir adalah adhal. Hal ini terjadi ketika anak perempuannya tetap ingin menikah dengan pilihannya.

Kelima; Perbedaan pilihan calon suami, ${ }^{31}$ hal ini sering terjadi ketika seorang anak sudah memiliki pilihannya sendiri dan orang tua (wali) sudah mempersiapkan calon untuk anaknya. Akibat dari perbedaan pilihan tersebut terjadinya pertengkaran dan pengusiran karena dianggap tidak patuh kepada orang tua. Ketika melihat dari konteks Islam, secara normatif Ayah memiliki kedudukan sebagai wali mujbir yang memiliki kewenangan untuk memaksa anaknya menikah. Hanya saja, ulama fikih dalam hal ini melarang para wali nikah menghalangi anaknya untuk menikah apabila kafa'ah. Bahkan Ibn Rusyd berpendapat bahwa tidak berhak bagi wali menghalangi anak yang diwalikannya menikah manakala ia menginginkan pasangan yang sekufu dan dengan mahar mitsil, maka apabila wali mencegah hendaklah bagi perempuat melaporkan perihal tersebut kepada hakim, maka menikah perempuan tersebut dengan wali selain bapak (wali aqrab). ${ }^{32}$

Hanya saja jika dilihat dari aspek sosiologis, kebanyakan para wanita menikah dengan pilihannya sendiri dan memfungsikan para walinya sebagai pertimbangan saja bukan sebagai penentu. Akibatnya, ketika orang tuanya tidak setuju dengan pilihan anaknya dan yang dilakukan anaknya adalah nikah lari atau nikah "liar". Hal ini yang sering terjadi di kota langsa sebagaimana hasil wawancara yang dilakukan di KUA Kota Langsa. Penyebab terjadinya permasalahan ini yaitu kurangnya komunikasi antara anak dan orang tua dimana

\footnotetext{
${ }^{29}$ A. H. Maslow, Motivation And Personality (India: Prabhat Prakashan, 1981).35

${ }^{30}$ Irham, Wawancara Kepala KUA Langsa Baro, June 20, 2019.

${ }^{31}$ Khalilurrahman, Wawancara Kepala KUA Langsa Lama.

32 Rusyd, Bidayatul Mujtahid Wa Nihayatul Muqtashid.
} 
orang tua sudah mempersiapkan calon yang menurutnya baik dan anak sudah memiliki calon pilihannya sendiri.

Dalam praktiknya, wali adhal memberikan dampak negatif terhadap keberlangsungan pernikahan. Tidak hanya itu saja, bahkan mempengaruhi psikologis rumah tangga anaknya. Berdasarkan data yang didapatkan dari hasil wawancara menunjukan bahwa ada tiga dampak yang terjadi akibat wali adhal. Antara lain;

1. Terjadinya nikah lari. rata-rata para mempelai mengambil inisiatif nikah lari dan menikah secara sirri dengan menggunakan jasa tokoh agama. Dampak ini akan berkelanjutan terhadap status anak ketika pernikahan yang dilakukan secara sirri.

2. Disharmonisasi antara anak dan wali

3. Pemutusan hubungan silaturrahmi.

Beberapa hal tersebut diatas merupakan dampak yang ditimbulkan ketika terjadinya wali adhal. Berdasarkan data tersebut menunjukan juga bahwa perihal wali tidak terlepas dari permasalahan, karena pernikahan tidak hanya melibatkan kedua mempelai saja melainkan melibatkan keluarga besar kedua belah pihak, sehingga izin dan restu orang tua menjadi hal penting dalam pernikahan karena ini akan berdampak berkepanjangan dalam membina rumah tangga.

\section{KUA dan Mahkamah Syari'iyah: Tinjauan Aspek Normatif dan Sosiologis Penyelesaian Wali adhal di Kota Langsa, Aceh}

Dalam pembahasan kali ini perlu dipertegas tentang kewenangan secara hukum penyelesaian wali adhal. Membahas mengenai kewenangan tidak terlepas dari kajian absolut dan relatif. Secara absolut Pengadilan Agama memeriksa dan mengadili perkara perkawinan, kewarisan, wasiat, hibah, wakaf dan shadaqah yang secara subtansi merujuk kepada hukum Islam. Kekuasaan absolut ini tidak dapat menyelsaikan perkara yang begitu kompleks dan berkembang didalam masyarakat seperti meyelesaikan masalah ekonomi Islam yang semakin marak dan berkembang dikalangan masyarakat, sehingga dalam paradigma masyarakat bahwa perkara yang dapat diselesaikan oleh Pengadilan Agama hanya tentang perkawinan dan waris saja.

Melihat pertumbuhan ekonomi syariah semakin pesat dan Untuk menyelesaikan sengketa dibidan ekonomi syariah, maka Undang-Undang Nomor 7 Tahun 1989 Tentang Peradilan Agama dirubah kedalam Undang-Undang Nomor 3 Tahun 2006 yang memberikan perluasan wewenang bagi Pengadilan Agama untuk memeriksa, memutus, dan menyelesaikan perkara ekonomi syari'ah. Untuk Perkara Perkawinan sebagaimana diatur dalam Undang-Undang Nomor 1 Tahun 1974 Tentang perkawinan, untuk perkara kewarisan, wasiat dan hibah sebagaimana yang telah diatur dalam Undang-Undang Nomor 3 Tahun 2006 Tentang Perubahan atas Undang-Undang Nomor 7 Tahun 1989 Tantang Peradilan Agama. Untuk perkara wakaf, zakat, infak dan shadaqah sebagaimana yang terdapat dalam Undang-Undang 
Nomor 38 Tahun 1999 Tentang Pengelolaan Zakat dan Undang-Undang Nomor 41 Tahun 2004 Tentang Wakaf. Selain itu, pihak Pengadilan Agama juga dapat menggunakan KHI dalam memutuskan perkara yang berkaitan dengan perdata Islam.

Salah satu yang tercakup dalam kekuasaan mutlak pengadilan dalam lingkungan peradilan agama adalah bidang perkawinan. Kekuasaan badan peradilan dibidang tersebut semakin bertambah, terutama sejak berlakunya Undang-Undang Nomor 1 tahun 1974. Menurut penjelasan Pasal 49 ayat 2 dalam Undang-Undang Nomor 7 Tahun 1989 Tentang Peradilan Agama, yang dimaksud dengan bidang perkawinan adalah:

1. Izin beristri lebih dari seorang

2. Izin melangsungkan perkawinan bagi orang yang belum berusia 21 tahun, dalam halo rang tua atau wali atau keluarga dalam garis lurus ada perbedaan pendapat

3. Dispensasi kawin

4. Pencegahan perkawinan

5. Penolakan perkawinan oleh pegawai pencatat nikah

6. Pembatalan perkawinan

7. Gugatan kelalaian atas kewajiban suami atau istri

8. Perceraian karena talak

9. Gugatan perceraian

10. Penyelesaian harta bersama

11. Mengenai penguasaan anak-anak

12. Ibu dapat memikul biaya pemeliharaan dan pendidikan anak bilamana bapak yang seharusnya bertanggung jawab tidak memenuhinya

13. Penentuan kewajiban member biaya penghidupan oleh suami kepada bekas istri atau penentuan suatu kewajiban bagi bekas istri

14. Putusan tentang sah atau tidaknya seorang anak

15. Putusan tentang pencabutan kekuasaan orang tua

16. Pencabutan kekuasaan wali

17. Penunjukan orang lain sebagai wali oleh pengadilan dalam hal kekuasaan seorang wali dicabut

18. Menunjuk seorang wali dalam hal seorang anak yang belum cukup umur 18 tahun yang ditinggal kedua orang tuanya padahal tidak ada penunjukkan wali oleh orang tuanya

19. Pembebanan kewajiban ganti kerugian terhadap wali yang telah menyebabkan kerugian atas harta benda anak yang ada dibawah kekuasaannya

20. Penetatapan asal usul seorang anak

21. Putusan tentang hal penolakan pemberian keterangan untuk melakukan perkawinan campuran 
22. Pernyataan tentang sahnya perkawinan yang terjadi sebelum UU No.1 tahun 1974 tentang perkawinan dan dijalankan menurut peratutan yang lain.

Berdasarkan Undang-Undang Nomor 7 Tahun 1989 Tentang Peradilan Agama jelas bahwa kewenangan menyelesaikan perkara wali adhal adalah Pengadilan Agama, meskipun tidak ditegaskan secara implisit, tetapi secara eskplisit bahwa yang berhak mencabut kekuasaan wali adalah Pengadilan Agama bukan KUA. Hanya saja, di Aceh Pengadilan Agama diterjemahkan kedalam Mahkamah Syar'iyah atau Peradilan Syari'ah sebagaimana dijelasakan dalam Undang-Undang Nomor 50 Tahun 2009 Tentang Perubahan atas Undang-Undang Nomor 7 Tahun 1989 dan Undang-Undang Nomor 11 Tahn 2006 Tentang Pemeritahan Aceh, jo Qanun Nomor 10 Tahun 2002 Tentang Peradilan Syariat Islam.

Secara relatif kewenangan Mahkamah Syar'iyah sama dengan Peradilan Agama. Akan tetapi, secara absolut Mahkamah Syar'iyah memiliki kewenangan lebih dari pada Peradilan Agama. Mahkamah Syar'iyah di Aceh selain mengadili perkara perdata Islam turut juga mengadili perkara aqidah, syar'iyah dan akhlak. Dibidang syar'iyah mencakup perkara hukum ahwal al-syakhsiyah (hukum keluarga), Muamalah (hukum ekonomi), Jinayah (Hukum Pidana Islam) dan Pembelaan Islam. ${ }^{33}$ sedangkan KUA memiliki kewenangan berdasarkan ketentuan Peraturan Menteri Agama Nomor 11 Tahun 2007 Tentang Pencatatan Nikah, Pasal 2 ayat (1) yang berbunyi;

Pegawai Pencatat Nikah yang selanjutnya disebut PPN adalah pejabat yang melakukan pemeriksaan persyaratan, pengawasan dan pencatatan peristiwa nikah/rujuk, pendaftaran cerai talak, cerai gugat, dan melakukan bimbingan perkawinan.

Berdasarkan Pasal 2 tersebut setidaknya menjelaskan bahwa ada dua poin penting tugas KUA sebagai PPN yaitu; Pertama, berkaitan dengan pencatatan nikah yang mencakup sebagai pegawas dan mencatat peristiwa nikah tersebut termasuk juga pencatatan rujuk dan cerai; Kedua, yaitu berkaitan dengan bimbingan perkawinan bagi calon penganting (kuscatin) yang bertujuan untuk memberi wawasan kepada calon pengantin dalam membina rumah tangga yang harmonis. Selain dua tugas pokok tersebut, KUA juga memiliki kewenangan untuk menjadi wali hakim bagi calon mempelai wanita yang tidak mempunyai wali. Hanya saja dalam praktiknya peran KUA cukup dominan dalam penyelesaian perkara wali adhal di Kota Langsa, Aceh, karena masyarakat memahami bahwa permasalahan wali adhal cukup dengan KUA saja sedangakan perkara perceraian baru dilakukan oleh Mahkamah Syar'iyah.

\footnotetext{
33 Nashihul Abror, "Eksistensi Dan Kewenangan Mahkamah Syar'iyah Dalam Mengadili Tindak Jinayah Di Provinsi Nanggroe Aceh Darussalam," Al-Jinâyah: Jurnal Hukum Pidana Islam 6, no. 1 (2020): 28, https://doi.org/10.15642/aj.2020.6.1.229-256.
}

M. Affas Edward| Ex Officio Kepala Kantor Urusan Agama .....| 83 
Secara sosiologis. Penyelesaian wali adhal lebih efektif ketika ditangani oleh pihak KUA karena metode penyelesaianya yang mengedepankan pendekatan kekeluargaan dan keagamaan, sehingga tidak terjadi permusuhan antara anak dan orang tu, sehingga akan menemukan penyelesaian yang bersifat win win solition. Berbeda ketika diselesaikan di Mahkamah Syar'iyah, ketika tidak menemukan titik temu maka putusan Mahkamah Syar'iyah akan bersifat menang dan kalah, sehingga dapat menghilangkan hak kewalian dalam pernikahan. Hal ini tentu menjadi kekecewaan dari pihak orang tua yang selama ini membesarkan dan mendidik anak tersebut. Upaya yang dilakukan oleh KUA yaitu mengusahakan ketika walinya adhal akan diupayakan pernikahan tersebut tetap dilakukan dengan walinya sendiri meskipun wakalah wali, karena wakalah wali juga diakomodir dalam hukum Islam dan dibolehkan. ${ }^{34}$ Sehingga seorang anak dapat melangsungkan pernikahan tanpa harus ke Mahkamah Syar'iyah.

Hanya saja dalam teori kewenangan setidaknya sekurang-kurangnya terdiri atas tiga unsur antara lain Pertama, Pengaruh; Kedua, Dasar hukum dan Ketiga, Konformitas hukum. unsur pengaruh yaitu yang menjelaskan bahwa penggunaan wewenang dimaksudkan untuk mengendalikan prilaku subyek hukum dan komponen dasar hukum yaitu yang menjelaskan bahwa wewenang itu harus diberikan berdasarkan hukum sedangkan komponen konformitas hukum mengandung adanya batasan atau standarisasi wewenang.

Ketika melihat teori kewenangan, maka kewenangan penyelesaian wali adhal kembali kepada Mahkamah Syar'iyah karena secara lagalitas dan pengaruh serta komfirmitas lebih mengarah kepada Mahkamah Syar'iyah. Akan tetapi, secara sosiologis efektifitas penyelesaian perkara wali adhal lebih efektif dan efisien dilakukan oleh pihak KUA, karena selain memahami kondisi masyarakat lokal, KUA juga memiliki hubungan emosional keagamaan dengan masyarakat sertempat sehingga permasalahan wali adhal dapat diselesaikan dengan pendekatanpendekatan yang telah dilakukan oleh KUA Kota Langsa, Aceh.

Peran KUA secara sosiologis telah dilakukan dengan berberapa strategi yang diupayakan oleh KUA agar tidak tidak terjadi wali adhal. Ketika tetap terjadi wali adhal akan diupayakan terjadinya perpindahan wali dengan cara wakalah wali, cara ini ditempuh agar pernikahan tetap terlaksana dan tidak perlu menempuh jalur litigasi yang akan banyak menyita waktu, energi dan psikologis. Ada beberapa pendekatan yang ditempuh KUA dalam menyelesaikan permasalahan wali adhla. Antara lain;

Pertama, Mediasi dengan orang tua agar mau menikahkan mereka, tetapi hal itu tidak bisa sekaligus kadang berhari-hari kita lakukan mediasi kadang berhasil dan kadang tidak berhasil. Pendekatan mediasi dengan pola mempertemukan wali dan calon mempelai dengan mendudukan permasalahan dan mencarikan solusi tepat agar tidak terjadinya pertengkaran yang berujung kepada permusuhan.

${ }^{34}$ Sayyid Sabiq, Fiqh Al-Sunnah, vol. 2 (Qahirah: Dâr al-Fath Li 'Ilmi al-'Arabi, 1995).207

M. Affas Edward| Ex Officio Kepala Kantor Urusan Agama ..... 84 
Mediasi merupakan hal pertama kali yang dilakukan oleh pihak KUA Langsa Lama, ${ }^{35}$ Langsa Baro, ${ }^{36}$ Langsa Kota ${ }^{37}$ dan Langsa Barat. ${ }^{38}$

Kedua, Pendekatan emosional dengan membujuk agar para wali nikah bersedia untuk menikahkan anaknya. Apabila wali menolah untuk menjadi wali nikah, pihak KUA akan membujuk meskipun pada akhirnya akan terjadi wakalah wali sehingga pernikahan dapat dilangsungkan. dengan seperti ini pernikahan dapat berlangsung dan terhindar dari nikah lari. Wakalah wali (taukil wali) diperbolehkan dalam Islam ketika wali tidak memenuhi syarat untuk menjadi wali. biasanya taukil wali dilakukan secara lisan yang dilakukan oleh wali nikah kepada pihak lain yang dianggap paham agama. ${ }^{39}$ dalam kontek ini kebanyakan para wali nikah mewakilkan kepada pihak KUA meskipun secara yuridis fungsi KUA sebagai pencatan nikah dan wali hakim bukan penerima taukil wali. hal ini menunjukan bahwa Kepala KUA sebagai PPN menjalankan tugas diluar kewenangannya secara hukum positif. Akan tetapi, sas-sah saja ketika masyarakat taukil wali kepada pihak KUA karena secara hukum Islam yang terpenting memenuhi syarat menjadi wali nikah. Secara sosioligs praktik ini kerap sekali terjadi dan tentunya pihak KUA sulit untuk menghindari karena stigma masyarakat Kota Langsa menganggap bahwa KUA sebagai PPN memiliki kapasitas dalam menikahkan para mempelai.

Ketiga, Musyawarah, ketika orang tuanya (wali) adhal. Maka, dilakukan musyawarah dengan keluarga besar mempelai dan turut menghadirkan tokoh masyarakat (tuha peut) untuk mencari solusi, dalam musyawarah lebih menekankan aspek negatif ketika terjadi wali adhal. Dengan kehadiran tuha peut semakin memperkuat argumentasi yang di paparkan oleh pihak KAU, kerena secara adat masyarakat sangat menghormati tuha peut sebagai orang tertua di Gampong.

Keempat, Litigasi, jalur ini ditempuh apabila ketiga pendekatan tersebut gagal, solusi terakhir yaitu menyarankan untuk membawa permasalahan wali adhal kepada Mahkamah Syar'iyah, karena secara hukum Mahkamah Syar'iyah memiliki kewenangan untuk menyelesaikan wali adhal.

Beberapa pendekatan tersebut pernah dilakukan oleh pihak KUA Kota Langsa. Namun, mayoritas setelah dilakukan dengan pendekatan tersebut berhasil meskipun dengan cara wakalah wali karena dalam hukum islam juga mengatur dan membolehkan dengan jalan wakalah wali. bahkan yang pada awalnya saling bermusuhan antara wali dan anak berubah menjadi akur karena proses yang digunakan oleh KUA nyatanya efektif tanpa menimbulkan permusuhan. Tentunya

\footnotetext{
35 Khalilurrahman, Wawancara Kepala KUA Langsa Lama.

36 Irham, Wawancara Kepala KUA Langsa Baro.

37 Fahmi, Wawancara Kepala KUA Langsa Kota.

38 Azhar, Wawancara Kepala KUA Langsa Barat,.

39 Oktaviani and Arif Sugitanata, "Memberikan Hak Wali Nikah Kepada Kyai: Praktik Taukil Wali Nikah Pada Masyarakat Adat Sasak Sade," Al-Ahwal: Jurnal Hukum Keluarga Islam 12, no. 2 (September 22, 2020): 161-72, https://doi.org/10.14421/ahwal.2019.12204.
} 
berbeda ketika diselesaikan oleh Mahkamah Syari'iyah, ketika gagal dilakukan mediasi. Maka, hakim dapat mencabut hak wali karena adhal. Tentunya hal ini akan berdampak secara psikologis terhadap rumah tangga anaknya. Karena pernikahan yang dibangun tanpa restu wali.

\section{Penutup}

Paradigma yang muncul pada masyarakat Kota Langsa tentang kewenangan menyelesaikan permasalahan wali adhal adalah KUA. Padahal secara hukum kewenangan tersebut adalah Mahkamah Syar'iyah. Akan tetapi, masyarakat menganggap bahwa KUA adalah lembaga yang mampu menyelesaikan permasalahan wali adhal tanpa mengakibatkan perselisihan, pertengkaran. Bahkan KUA dengan sukarela terjun langsung menjumpai para wali nikah untuk menyelesaikan konflik yang diakibatkan oleh wali adhal. Dalam kondisi seperti ini KUA bersifat aktif berbeda dengan Mahkamah Syar'iyah yang bersifat pasif menunggu perkara yang masuk.

\section{Daftar Pustaka}

Abror, Nashihul. "Eksistensi Dan Kewenangan Mahkamah Syar'iyah Dalam Mengadili Tindak Jinayah Di Provinsi Nanggroe Aceh Darussalam." AlJinâyah: Jurnal Hukum Pidana Islam 6, no. 1 (2020): 28. https://doi.org/10.15642/aj.2020.6.1.229-256.

Aini, Siti Maryam Qurotul. "Kedudukan Wali Dalam Pernikahan (Kajian Perbandingan Madzhab)." USRATUNA 1, no. 1 (2017): 20.

As- Syafi'I, Abi Abdillah Muhammad bin Idris. Al-Umm. Vol. 3. Beirut: Dār Al-Fiqr, 1983.

Asith, Hilma Syita El. "Dasar Pertimbangan Hakim Dalam Permohonan Wali." $A L$ HAKIM: JurnalImiahMahasiswa : Studi Syariah, Hukum danFilantropi 2, no. 2 (2020): 13.

Azhar. Wawancara Kepala KUA Langsa Barat, June 17, 2019.

Fahmi, Itqan. Wawancara Kepala KUA Langsa Kota, June 18, 2019.

Irham. Wawancara Kepala KUA Langsa Baro, March 5, 2019.

-_- Wawancara Kepala KUA Langsa Baro, June 20, 2019.

Jaziri, Abdu al-Rahman al-. Al-Fiqh 'Ala Al-Mazâhib Al-Arba'Ah. Vol. 4. Beirut: Dār Al-Kutub Al-'Ilmiyah, 1990.

Jaziri, Abdurraḥman al-. Kitab Al-Fiqh Alal Mazahib al-Arba'ah. Vol. 3. Beirut: Dār al-Fikr, tt.

Khalilurrahman. Wawancara Kepala KUA Langsa Lama, June 17, 2019.

Maslow, A. H. Motivation And Personality. India: Prabhat Prakashan, 1981.

Moch. Azis Qoharuddin. "Kedudukan Wali Adhal Dalam Perkawinan." El-Faqih: Jurnal Pemikiran dan Hukum Islam 4, no. 2 (October 30, 2018): 99-122. https://doi.org/10.29062/faqih.v4i2.44. 
Mubarok, Muhamad Affan, Eva Fauziah, and Ilham Mujahid. "Tinjauan Kompilasi Hukum Islam (KHI) terhadap Putusan Hakim Tentang Perkawinan Wali Adhal." Prosiding Hukum Keluarga Islam 6, no. 2 (2020): 38-31. http://dx.doi.org/10.29313/islamic\%20family.v6i2.22207.

Muhamad Hasan Sebyar, and A. Fakhruddin. "Pengambilalihan Wewenang Wali Nasab Dalam Perkara Wali Adhal Perspektif Pluralisme Hukum (Studi Kasus Pandangan Hakim dan Tokoh Masyarakat Kabupaten Pasuruan)." ADHKI: Journal of Islamic Family Law 1, no. 2 (February 4, 2020): 73-91. https://doi.org/10.37876/adhki.v1i2.19.

Muhazir. Wawancara Akademisi, October 15, 2020.

Mustafa Al-Jin, Mustafa Al-Bugha. Fiqh Âl-Manhaji 'ala Mazhab Al-Imâm Al-Syâfi'i. 13th ed. Vol. 2. Damsyik: Dâr al-Fâth, 2012.

Nawawi, Al-Imam. Raudhatu At-Thâlibin. Vol. 5. Saudi Arabiya: Dâr 'Alam Al-Kutub, 2003.

Nurcholis, Moch. “Usia Nikah Perspektif Maqashid Perkawinan.” Tafáqquh: Jurnal Penelitian Dan Kajian Keislaman 8, no. 1 (March 16, 2020): 1-18.

Oktaviani, and Arif Sugitanata. "Memberikan Hak Wali Nikah Kepada Kyai: Praktik Taukil Wali Nikah Pada Masyarakat Adat Sasak Sade." Al-Ahwal: Jurnal Hukum Keluarga Islam 12, no. 2 (September 22, 2020): 161-72. https://doi.org/10.14421/ahwal.2019.12204.

Rafiq, Aayesha. "Role of Guardian in Muslim Woman's Marriage: A Study In The Light Of Religious Texts." IJISET - International Journal of Innovative Science, Engineering \& Technology 2, no. 4 (n.d.): 8.

Ramadhan, Dian, and Farah Ihza Fauzia Balqis. "Pandangan Mazhab Hanafi Dan Maliki Terhadap Jumlah Kadar Mahar Pada Akad Nikah." JAWI 3, no. 1 (2020): 18. http://dx.doi.org/10.24042/jw.v3i1.7036.

Rokhmadi, Rokhmadi. "Penetapan 'Adam Wali Nikah Oleh Pejabat Kua Di Kota Semarang.” Al-Ahkam 26, no. 2 (December 2, 2016): 203. https://doi.org/10.21580/ahkam.2016.26.2.992.

Rusyd, Ibnu. Bidayatul Mujtahid Wa Nihayatul Muqtashid. Translated by AlMas'udah. Vol. 2. Jakarta: Pustaka Al-Kautsar, 2016.

Sabiq, Sayyid. Fiqh Al-Sunnah. Vol. 2. Qahirah: Dâr al-Fath Li 'Ilmi al-'Arabi, 1995.

Shodikin, Akhmad. "Penyelesaian Wali Adhal Dalam Pernikahan Menurut Hukum Islam Dan Perundang-Undangan Di Indonesia." Mahkamah: Jurnal Kajian Hukum Islam 1, no. 1 (2016): 10.

Sulaiman al-Asy’ats al-Sijistani, Abu Daud. Sunan Abi Daud. Vol. 2. Beirut: Maktabah al-'Ashriyyah, tt.

Syarifuddin, Amir. Hukum perkawinan Islam di Indonesia: antara fiqh munakahat dan Undang-Undang Perkawinan. Jakarta: Kencana, 2006.

Zuhaily, Wahbah. Fiqh Islamî Wa Adillatuh. Vol. 9. Beirut: Dār al-Fikr, 1997. 